\title{
A Re-Vision of To Kill a Mockingbird and Roll of Thunder, Hear My Cry
}

As a middle and high school English teacher of ten years, and an avid reader since I was a young child, I have read hundreds of children, young adult, and adult books. Over those years, I have read and taught a wide range of books from many cultures, ethnicities, genders, and topics. I prided myself in the multicultural literature that I was able to expose my students to, particularly knowing that the literary canon is still filled with mostly dead White males. Interestingly, however, it was not until I took a course on children's and young adult literature, during my doctoral studies, that I read Roll of Thunder, Hear My Cry (ROTHMC) by Mildred Taylor.

As I read the book with my fellow doctoral students, I was irritated that I had not read it until my middle thirties. It was not that I had not heard of the book before; I was well aware that the book was taught in some schools and that it had won some awards. But, somewhere along my then 35 years of life, it had never once been recommended to me or taught to me. In reading it for the first time, it reminded me of To Kill a Mockingbird (TKAM) by Harper Lee, a book that I have cherished as reader and taught to my students each year. Yet, when I finished Roll of Thunder, I wondered how did these two stories that are remarkably similar, end up on such different trajectories in terms of their notoriety, success, and teachability. Why is To Kill a Mockingbird, a classic canonical text, taught widely across the United States, and Roll of Thunder, Hear My Cry not, especially considering their similar settings, themes and characters?

Both books have received critical acclaim, but only one has reached iconic heights. To Kill a Mockingbird, written by Nelle Harper Lee in 1960, was commercially successful 
from the moment it was published. Set in a small Alabama town in the 1930s during the Depression, this novel is a tale of innocence, prejudice and courage, told through the eyes of Scout Finch, a six-year-old tomboy. Weaving two plots together, Scout draws the reader into tales about her brother Jem, their friend Dill, and her own adventures understanding their mysterious neighbor, Boo Radley, and why a young Black man, Tom Robinson, would be accused of raping a White woman. Atticus Finch, Scout and Jem's father, is appointed to defend Tom and helps his children to understand the racism and injustice in their worlds. This book has won many awards. In 1961, in addition to the Alabama Library Association's Literary Award, it also received the esteemed Pulitzer Prize for fiction. Additionally, it won the Brotherhood Award of the National Conference of Christians and Jews in 1961, and the Paperback of the Year award from Bestsellers magazine in 1962. The American Library Association named it the best book of the $20^{\text {th }}$ century and the Library of Congress declared in 1991 that it was second only to the Bible in terms of its influence on people's lives (Anderson, 2010).

Similarly, Roll of Thunder, Hear My Cry written by Mildred Taylor in 1976, was also critically successful. Set in a small Southern town at the height of the Depression, this novel also deals with issues of prejudice, courage, and self-respect. Told through the eyes of Cassie Logan, an independent Black girl, the reader learns the story of the Logan family's struggle to maintain their Mississippi land. They do this with humor, integrity and pride in the face of blatant racism and social injustice, and boldly help their neighbors and friends despite the very real risks to their own lives. Roll of Thunder has received numerous honors including the prestigious 1977 Newbery Medal. The book was also a National Book Award finalist, an American Library Association (ALA) Notable Book, a Jane Addams Peace 
Association honor book, a National Council for the Social Studies / Children's Book Council Notable Children's Trade Book in the Field of Social Studies, a Coretta Scott King Honor Book, and a Boston Globe-Horn Book Award Honor.

Interestingly, one would assume that both of these books would have become instant classics based on their copious awards. Yet, this appears not to be the case. In previewing many book lists, I have seen a disturbing trend. To Kill a Mockingbird is almost always listed as one of the best books of all time, and Roll of Thunder, Hear My Cry is nowhere to be seen at all or relegated to the children's literature or multicultural literature lists only. In 1998, the Modern Library's readers voted on To Kill a Mockingbird as the $5^{\text {th }}$ best book of all time, the Radcliffe Publishing Course listed it as \#4, and the 2012 NPR survey of the Top 100 Teen Books included To Kill a Mockingbird at \#3. Roll of Thunder was not found on any of these lists. In 2000, the National Education Association (NEA) surveyed kids, and in their Top 100 Books, To Kill a Mockingbird ranked \#94, while Roll of Thunder was not listed. In Time Magazine's 2005 ranking of the 100 Best Books from 1923 through today, in Common Sense Media's 2014 list of 50 books children should read before the age of 12, and in the Young Adult Library Services Association's (YALSA) Ultimate YA Bookshelf list, To Kill a Mockingbird was listed on all, but Roll of Thunder was not listed on any.

So where was Mildred Taylor's critically acclaimed book in all of these lists? It took some digging, but eventually I found three lists that included it. Anita Silvey (former editor of The Horn Book) listed Roll of Thunder, Hear My Cry as one of the 100 best children's books for 11-12 year olds (a quite specific placement!). The 2012 Children's Books Guide's 100 Best Children's Chapter Books also included Roll of Thunder among its list. Additionally, the Cooperative Children's Book Center, listed Roll of Thunder, Hear My Cry as 
one of the 50 multicultural books every child should read in 2010, but in the two most recent updates the cooperative has taken the book off the list. It should be noted too that none of these children's or multicultural book lists included To Kill a Mockingbird.

The fact that I had to go to somewhat obscure book lists to find Roll of Thunder mentioned is interesting and odd. First of all, why is Taylor's book only listed in children's books? It was never listed in young adult book lists or plain-old regular book lists. In contrast, To Kill a Mockingbird is almost exclusively found in non-children's book lists despite the fact that the main character is a 6-year-old girl. From an English teacher's perspective, I cannot reasonably argue that Harper Lee's book is any harder, more mature, or more literary than Mildred Taylor's book. However, some might argue this is because To Kill a Mockingbird is not YA literature or children's literature because the narrator is actually an adult reminiscing on childhood. Yet, I would argue that categorizing books in this way is more complex than who is narrating.

Although definitions of what constitutes YA literature, children's literature, and adult literature are hard to pin down, I personally like L'Engle's (2001) definition in her book Walking on Water: Reflections on Faith and Art. She writes that "a children's book is any book a child will read" (p. 114). Furthermore, perhaps more persuasive is the way in which books are marketed by their publishers, which Nodelman (2008) says is the most pragmatic way to delineate children's and young adult books from adult books. Both To Kill a Mockingbird and Roll of Thunder are marketed for youth, not adults, although many adults clearly read and enjoy these novels. The way in which companies, publishers, and mass culture websites list books in award categories, as just discussed, also highlights how books are viewed and categorized. Based on the aforementioned reasons, I must conclude that the 
only reason, Roll of Thunder, which has received so many awards, is absent from all of these "best books" lists, and is relegated to just the children's lists even though TKAM and ROTHMC are equivalently youth oriented, must have something to do with race. I hope not, but I have a sneaking suspicion that the same reason I had not read the book, been taught the book, or saw it on the majority of these lists has to do with something called "the selective tradition."

\section{The Selective Tradition}

As teachers, and as schools, we have a unique responsibility of selecting books for our students to read. Often teachers are unaware that their own ideologies guide their book selections. Martorana (2013), however, argues that investigating and acknowledging our own ideologies is important because our choices "send messages of power to our students, communicating and reinforcing what is appropriate and valued" (p. 216). In the case of choosing To Kill a Mockingbird, Ricker-Wilson (1998) notes:

I had to make a quick decision about which core novel I would teach a grade eleven English class. Should it be that highly contested work from the traditional North American literary canon, To Kill a Mockingbird, or should I search for a comparable work by a black writer that examined the multiple and complex, tragic, and absurd interactions of blacks and whites living under Jim Crow? (p. 67)

These decisions do not come easily. There are a range of complicated contextual and personal factors that influence teachers' decisions regarding what they read in the classroom (Watkins \& Ostenson, 2015). Unfortunately, teachers often "lack the courage to present non-mainstream perspectives and experiences, and they lack faith in children's ability to recognize and handle difficult issues" (Wollman-Bonilla, 1998, p. 287). Yet, Juzwik 
(2013), in her article on teaching difficult texts (specifically Holocaust literature), implores educators to consider the importance of teaching texts ethically, and consider the implications and impact of texts on their intended audiences. When teachers lack the courage to fully explore historical and troubling topics related to race, for example, from multiple perspectives with their students, teachers are making a conscious choice to include certain ideologies to the exclusion of other, often non-mainstream, ideology.

This process is a part of what Williams (1977) called the selective tradition. He defined the selective tradition as "an intentionally selective version of a shaping past and pre-shaped present, which is then powerfully operative in the process of social and cultural definition and identification" (p. 115). This means that certain ideas and practices of the past are promoted and emphasized, while others are excluded or forgotten. Apple (2004b) calls this practice a privileging of "official," or "high status knowledge," in which a majority groups' choices shape our collective unconscious, and legitimize and perpetuate hierarchies of race, class, and gender. Apple (2004a) argues that in schools, "Texts are really messages to and about the future. As part of a curriculum, they participate in no less than the organized knowledge system of society. They participate in creating what a society has recognized as legitimate and truthful" (p. 182). For classrooms that are becoming (and largely have always been) diverse, this is problematic. These exclusionary choices "diminis[h] the legitimacy of one group in favor of another and presen[t] students with an ideologically biased, culturally exclusive, and ultimately false view of society" (Jipson \& Paley, 1991, p. 148). Not only does the selective tradition give students a diminished view of society, but it also alienates the voices of many of our students who are not in the majority. As Glazier and Seo (2005) attest, with these selective choices, the "school 
curricula confirm and privilege students from the dominant culture while excluding and often disconfirming the experiences of subordinate groups" (p. 887). The canon, the prestigious list of "best" literature, is a perfect example of the selective tradition. Within this tradition, women, parallel culture groups (otherwise known as racial and ethnic minorities), certain social classes, and sexual orientations are excluded from the canon in favor of books with White, Eurocentric, male authors and subjects (Applebee, 1990; Glazier \& Seo, 2005; Jipson \& Paley, 1991; McNair, 2010). In terms of children's literature, traditional classic contemporary works are almost overwhelmingly written by White authors (McNair, 2010). Unfortunately, the stories of authors and characters from other cultures are "left on the margins - silenced" (Glazier \& Seo, 2005, p. 887).

The selective tradition and its ability to silence and marginalize minority voices has negative effects for both students who are marginalized and those who are in the privileged group. In Mildred Taylor's (1985) Newbery Award Acceptance Speech for Roll of Thunder, Hear My Cry, she says:

There were no Black heroes or heroines in those books; no beautiful Black ladies, no handsome Black men; no people filled with pride, strength, or endurance. There was, of course, always mention of Booker T. Washington and George Washington Carver; Marian Anderson and occasionally even Dr. Ralph Bunche. But that hardly compensated for the lackluster history of Black people painted by those books, a history of a docile, subservient people happy with their fate who did little or nothing to shatter the chains that bound them, both before and after slavery. There was obviously a terrible contradiction between what the books said and what I had learned from my family, and at no time did I feel the contradiction more than when I 
had to sit in a class which, without me, would have been all white, and relive that pride-less history year after year.

This quote is a priceless indictment of the problems of the selective tradition for minority students. But White students, who read only books reflecting their own experiences, are also at a disadvantage. Often, these students "take for granted the benefits of seeing themselves in what they read. Being forced to the margins all the time is disempowering, but for those ensconced in the center, the margins can provide powerful new perspectives" (Barker, 2010, p. 122). While teachers might feel they are protecting their students, in fact they are harming them by continuing the ideologically troubling practice found in the selective tradition.

While To Kill a Mockingbird is on the one hand an example of the success of a female author in becoming part of the selected tradition, on the other hand, the fact that she is a White woman who is writing about racism in the South needs to be taken into account. Why is her story of racism, told through the viewpoint of a White girl, the one that is cherished, when an equally powerful and well-written book by Mildred Taylor, told through the viewpoint of a Black girl, is less cherished? As Luke (1991) writes, “Because literacy teaching is never neutral, we will need to take responsibility for which literacies we introduce to students, because the decisions we make will greatly influence their life chances - how they are able to access knowledge and sociocultural power" (p. 142). Teachers need to begin thinking about how to be more aware of the ideology they are spreading to their students and how their book choices are an extension of an ideology of what is acceptable and preferred and what is not. What is needed is a "Re-vision - the act of looking back, of seeing with fresh eyes, of entering an old text from a new critical 
direction...Until we understand the assumptions in which we are drenched we cannot know ourselves" (Rich, 1972, p. 18). In some ways this re-visioning of texts is similar to the type of reading that Apple (2004b) calls "oppositional reading," where a reader "rejects these dominant tendencies and interpretations...[and] 'repositions' herself or himself in relation to the text and takes on the position of the oppressed" (p. 191). It is within this vein that I will re-view To Kill a Mockingbird and Roll of Thunder, Hear My Cry.

\section{To Kill a Mockingbird Meets Roll of Thunder, Hear My Cry}

Much can be gained by doing a comparative reading of To Kill a Mockingbird and Roll of Thunder, Hear My Cry. I wholeheartedly agree with McNair (2010) who writes that "Classic children's books written by African Americans and other groups of color deserve to be read alongside classics that are written by Whites. They too should be a part of all children's experiences" (p. 96). I believe that by placing these two novels in tandem, it becomes pretty apparent that To Kill a Mockingbird offers a very different, and in some ways lacking, voice and point of view on the subjects of race, privilege and justice than that of Roll of Thunder. This is not to say that To Kill a Mockingbird is not a great novel, but perhaps each offer critically different points of view and ideological perspectives.

While both books deal with racism in the South during the 1930s, one is about the Logan family (who are Black) and one is about the Finch family (who are White). Both texts are written by female Southern writers, but again one is told from the perspective of a Black woman and the other from a White woman. By examining how race, discrimination and prejudice are constructed and deconstructed in these two great pieces of historical fiction, I hope to highlight ideological assumptions and functions of the books. Both books have merit, but they do raise some questions about whose work offers the most legitimate 
voice on these topics. It is my hope that the comparison will begin a dialogue about why one book is relegated to the middle school (if at all), while the other has been canonized and widely taught in middle school through college courses, especially when thinking about the authenticity of these stories. (See Common Core State Standards Appendix B, exemplar texts, for "supposed" appropriate placement of TKAM and ROTHMC). I cannot possibly cover all the of the examples of race and (in)justice that these two books provide, but I hope that by examining comparable passages from each text, you will begin to see the benefit of using these books in tandem to (de)construct ideology. For the purposes of comparison, I will focus on two topics: (1) parental figures and familial advice, and (2) history of land ownership. These topics will provide two different entry points for which these discussions about the construction of race and injustice can occur.

\section{Parental Figures and Familial Advice}

The biggest way that prejudice and injustice are (de)constructed in these two novels is through the Finch and Logan families. In To Kill a Mockingbird, Atticus Finch, the father, acts as a moral compass for his children. As a lawyer, he is expected to take an impartial stance on issues related to the law. But impartiality does not mean that Atticus is without opinion. Although he is "not supposed to lean" (Lee, 1960, p. 208) one way or another, Atticus clearly does throughout the book. Interestingly, critics are mixed about Atticus as a role model for his children. Some feel he is almost too perfect, and Christ-like (Baecker, 2010), while others feel he is loving and supportive in a down-to-earth, heroic way (Helms, 2010; Phelps, 2010). Scout and Jem also do not quite know what to make of their own father. They seem to not really know their father too well, being surprised by tidbits they learn about him - for example, that he is "the deadest shot in Maycomb County" (Lee, 1960, 
p. 98). Overall, Jem and Scout reckon he is "satisfactory: he played with us, read to us, and treated us with courteous detachment" (Lee, 1960, p. 6). Perhaps this detachment can be explained by his age, but as Scout tells us, he "practiced economy more than anything" (Lee, 1960, p. 5). But, another reason he may be detached could be the fact that he is not really present in their lives. Rather than raise his own children, he has his Black cook and housekeeper, Calpurnia, take care of the children while he is gone all day. Despite his busy schedule, one of the acts that Atticus does well is provide guidance to Scout, our narrator and his daughter. According to Crowe (1999), "Without Atticus in To Kill a Mockingbird, Scout would be unable to understand or cope with the horrible events that take place in her small town" (p. 121).

In the scene I have chosen, Scout asks Atticus if he "defends niggers" (Lee, 1960, p. 75). Atticus responds, “Of course I do. Don't say nigger, Scout. That's common" (Lee, 1960, p. 75). Within this simple $Q / A$, we are already at the heart of (de)constructing race in this book. Scout is innocent to the world around her, and at this point does not know that "niggers" is not an appropriate word. However, Atticus's answer while on the surface appears to be the ethically correct way of responding to a racial slur, actually highlights a disdain for the "common" and irreverence towards race. Atticus's response highlights the Finch family's status and class as being above the rest of the town folk. One could argue, he looks down upon those with less fortune and is himself ignorant of the implications of the word. He just knows that it is not a word that people from "rich" family heritages would use.

Scout continues her questioning and asks: "'Do all lawyers defend n-Negroes, Atticus?" (Lee, 1960, p. 75), to which Atticus replies, that yes, he's "simply defending a 
Negro-his name's Tom Robinson" (Lee, 1960, p. 75). Even though people think he “shouldn't do much about defending this man" (Lee, 1960, p. 75), Atticus explains to Scout that he is defending him because

if I didn't I couldn't hold up my head in town, I couldn't represent this county in the legislature, I couldn't even tell you or Jem not to do something again...Because I could never ask you to mind me again. Scout, simply by the nature of the work, every lawyer gets at least one case in his lifetime that affects him personally. This one's mine, I guess. You might hear some ugly talk about it at school, but do one thing for me if you will: you just hold your head high and keep those fists down. No matter what anybody says to you, don't you let 'em get your goat. Try fighting with your head for a change... it's a good one, even if it does resist learning. (Lee, 1960, pp. 75-76)

There are multiple insights to be gained from this dialogue regarding the way injustice and race are (de)constructed. Just as Atticus never actually told Scout what was wrong with the word "nigger," he also does not ever actually defend Tom. He again comes across as flippant with his word choice of "simply", and in another part of his speech he claims that Calpurnia says "they're clean-living folks" (Lee, 1960, p. 75). He himself will not go so far as saying they are clean-living. Also noticed in this dialogue is an implication that Atticus has taken on this case because it would look bad if he did not. It again is not really about Tom Robinson. It is all about Atticus and how it personally affects him. Nowhere in his discussion does he talk about how this trial might affect Tom and his family. Furthermore, even if one could put all of these problems aside, Atticus is intentionally teaching his daughter to be an enabler of racism. By telling her to use her head and not her 
fists, it ultimately causes Scout to take a passive role when someone speaks badly about her father or anyone else who supports Tom's cause. Instead of teaching Scout to stand up for herself, in effect he teaches her to be a "a cow—ward!" (Lee, 1960, pp. 76-77) against racism and prejudice.

In Roll of Thunder, Hear My Cry, the Logan family has multiple members who offer guidance about how to deal with injustice and racism that surrounds them. This advice is drastically different to the advice that Atticus gives Scout. Both Mary and David Logan help their children learn the realities of being Black in the 1930s Deep South. But Uncle Hammer and Big Ma also play their role too. In this novel, one gets the sense that in the Logan household, children are not raised by themselves or by nosey neighbors, as is the case in To Kill a Mockingbird. The Logans do not rely on outside help to raise their children. I think that this is important to note because much literature on African American families includes stereotypical portrayals of the absent father, or parents (Sims, 1982; Sims Bishop, 2012). In the case of these two novels, Atticus Finch, a White male, more readily fits that mold. Similar to To Kill a Mockingbird, though, is the fact that David, Cassie's father, plays an extremely important role in helping her understand the hate-based acts and injustices in their community. Crowe (1999) writes that "Without David in Roll of Thunder, Hear My Cry, Cassie and her family would not survive and rise above the oppression and racism that surround them" (p. 121).

In this following scene, Cassie Logan has just returned from a traumatic trip to Strawberry with her grandmother where she is belittled by a store owner, called "nigger" several times, and is forced to apologize to her White classmate Lillian Jean because she accidentally bumped into her. Cassie tells us in all sincerity: "No day in all [her] life had 
ever been as cruel as this one" (Taylor, 1976, p. 116). Each member of her family has some advice for Cassie about how to understand this situation. But Mary and David Logan, her parents, give the most useful advice. Mary tells Cassie that she "had to grow up a little today," and that Cassie needed "to accept the fact that in the world outside this house, things are not always as we would have them to be" (Taylor, 1976, p. 126). Mama tells Cassie that Mr. Simms and Lilly Jean acted that way because "she's white." Cassie still does not understand, saying “'Ah, shoot! White ain't nothin'!' (Taylor, 1976, p. 127). Yet, Mama expounds:

It is something, Cassie. White is something just like black is something. Everybody born on this earth is something and nobody, no matter what color, is better than anybody else...he's one of those people who has to believe that white people are better than black people to make himself feel big...For him to believe that he is better than we are makes him think that he's important, simply because he's white....White people may demand our respect, but what we give them is not respect but fear. What we give to our own people is far more important because it's given freely...Baby, we have no choice of what color we're born or who our parents are or whether we're rich or poor. What we do have is some choice over what we make of our lives once we're here...And I pray to God you'll make the best of yours" (Taylor, 1976, pp. 127-129)

Several matters about this exchange are noteworthy. First of all, Mary is straightforward in explaining the realities of life as a Black girl to Cassie. She gives Cassie examples of the types of behaviors she has to do and why she has to do that. Although Cassie is as naive as Scout in her understanding of race and privilege, Cassie is given better 
advice as to how to handle the situations that she is given. Both Atticus and Mary ask their children to use their head and figure out what choice is the better one to make. But in this case Mary's lesson to her daughter is one of love and faith (as evidenced by her religious prayer), and not pride. It is one of concern for both her daughter's physical and psychic/spiritual safety.

David, Cassie's father, also gives some advice, that in the end Cassie takes to heart. After Cassie explains what happened in Strawberry, he says, "You know the Bible says you're s'pose to forgive these things... S'pose to turn the other cheek... But the way I see it, the Bible didn't mean for you to be no fool" (Taylor, 1976, pp. 174-175). He continues his discussion by telling Cassie that they are similar, but she has

a bad temper like [her] Uncle Hammer. That temper can get you in trouble... Cassie, there'll be a whole lot of things you ain't gonna wanna do but you'll have to do in this life just so you can survive. But there are other things, Cassie, that if I'd let be, they'd eat away at me and destroy me in the end. And it's the same with you, baby. There are things you can't back down on, things you gotta take a stand on. But it's up to you to decide what them things are. You have to demand respect in this world, ain't nobody just gonna hand it to you. How you carry yourself, what you stand for that's how you gain respect. But, little one, ain't nobody's respect worth more than your own. You understand that!... (Taylor, 1976 pp. 175-176)

Similar to his wife Mary's advice, David explains that as a Black girl she is going to have to deal with a lot of unfairness in her life and she has to choose the way she is going to handle the situation. Like Atticus, David talks about how not doing the right thing might destroy a person. But again, because David is coming from a marginalized position, it is not 
a selfish admission here. Rather in this case, he is trying to connect to his daughter's pain. He basically tells her they are similar and that he can understand why she might want to get revenge, but that there are consequences to those actions and one has to be sure whether they are the right actions to take. Rather than telling Cassie to back down, he tells her to pick her battles wisely, weigh the consequences of her actions, know what she stands for, and respect herself. This advice gives Cassie the courage to confront her racist classmate Lillian Jean in the most subversive act against her racist tendencies.

\section{History of Land Ownership}

History also plays a very important role in the (de)construction of racism and privilege. Related to history of the South in particular, is the notion of property, land, and land ownership. Each novel has moments where the history of their families is discussed in relation to the land they possess. These narrations and stories help to illustrate how racism is a long-held practice rooted in an unjust economic system.

For example, in To Kill a Mockingbird, Aunt Alexandra is set on teaching their history as a family, but other bits of history are told by Scout, the narrator, and indicate a very interesting past the Finch family has had. Since the passages are long, I will only highlight some of the most interesting facts Scout tells us about their family history. She writes, "Being Southerners, it was a source of shame to some members of the family that we had no recorded ancestors on either side of the Battle of Hastings. All we had was Simon Finch, a fur-trapping apothecary from Cornwall whose piety was exceeded only by his stinginess" (Lee, 1960, p. 3). The only reason why not knowing where you come from would be a source of shame is that it would make the Finch family appear to be of a lower class or status in their society. If you do not know where your family is from, then there is a slim 
but palpable chance that your family is from Africa. Many slaves also did not know their heritage. If the Finches were truly working towards justice for someone like Tom Robinson, then I doubt they would be so worried about their ancestral line.

Scout continues her historical musings by telling us that "In England, Simon was irritated by the persecution of those who called themselves Methodists at the hands of their more liberal brethren" (Lee, 1960, p. 3). Once he moved to America though, "Simon, having forgotten his teacher's dictum on the possession of human chattels, bought three slaves and with their aid established a homestead on the banks of the Alabama River some forty miles above Saint Stephens" (Lee, 1960, p. 4). Although one cannot claim that Atticus is anything like his ancestor, it is of importance that we find out that the Finches once owned slaves, despite it being hypocritical to his religious beliefs. Additionally we learn that Atticus was the first in his family to break "the tradition of living on the land" when he "went to Montgomery to read law" (p. 4). It is possible to conclude that perhaps this breaking away from the land indicates his breaking away from racist ideology. This could be considered the case, except that when Atticus passed the bar, "he returned to Maycomb and began his practice" (p. 4) because "he liked Maycomb, he was Maycomb County born and bred; he knew his people, they knew him, and because of Simon Finch's industry, Atticus was related by blood or marriage to nearly every family in the town" (Lee, 1960, p. 5). Within this statement there are a lot of hidden racist messages. Given that this is the South, and there are many Black families living in the area, I find it hard to believe that when Atticus says he was related by blood or marriage to nearly every family in town, that he was including the Black families. Statements like this indicate a subtle racist ideology that filters through even with Atticus Finch, our heroic father figure. He came back to Maycomb for 
"his" people, which most definitely meant his White Southern friends. The historical information we are given in this story through Scout is laden with ideology that actually supports and tolerates racism.

In Roll of Thunder, Hear My Cry, the history of land ownership is also quite important in understanding the racist tensions that the Logan family is faced with. The novel outlines a lot of historical events related to slavery, lynchings, and firebombings, and while all of this history is important to (de)constructing the ideologies around privilege and racism, I have chosen a different history to talk about that is equally, if not more important to the development of the story. This history relates to property and land.

The fact that a Black family in the 1930s could and did own land is a tale that many people in America would not be familiar with. Yet, we learn from Cassie that their land, that they own is protected and delineated by a line of "dense forest." Beyond this area is Harlan Granger's land, filled with "vast farming fields, worked by a multitude of share-cropping families" (Taylor, 1976, p. 6). Most interestingly, we learn that the Logan land had once "been Granger land too, but the Grangers had sold it during Reconstruction to a Yankee for tax money" (Taylor, 1976, p. 6). This detail constructs for us a reason for why the Grangers cause the Logan family unending trouble throughout the book.

Big Ma takes the story over telling us that the Yankee tried to sell the land back to the Grangers, but "but that old Filmore Granger was just 'bout as tight with a penny as anybody ever lived and he wouldn't buy it back" (Taylor, 1976, p. 91). It was then that Big Ma's husband, Cassie's grandpa, bought 400 acres of the land. We also learn that besides grandpa and some other farmers, "Mr. Jamison bought the rest...Charles Jamison was his name...A fine old gentleman, too. He was a good neighbor and he always treated us fair... 
just like his son..."(Taylor, 1976, p. 91). But soon after that, Harlan Granger got crazy and decided he wanted all his land back. Mr. Jamison sold all of it back to him when his father dies except for 200 acres. Big Ma tells us that "He could've just as easy sold the full thousand acres to the Grangers and gotten more money, but he didn't ... and till this day Harlan Granger still hold it 'gainst him 'cause he didn't." (Taylor, 1976, p. 93). Several important points are made in this historical monologue by Big Ma. First of all, we learn that there are different kinds of people in this society - people who are to be trusted and people who are not. Mr. Jamison and the Yankee are trustworthy, or at the very least unaffected by the color of people's skin. This history helps to paint a picture that not all White people were racist, ignorant and cruel. Yet, some were. Mr. Granger would fall into this latter category.

Additionally, we understand as well why Mr. Jamison and Mr. Granger have differing opinions of the share-croppers getting their supplies from another store. As Big Ma says, the Jamison's have also been fair people, whereas the Grangers are greedy and selfish and only want the cotton spoils and profit. Because the Logan family has land, this puts them in a different class than other people in their society. Even the Wallace family, a White family who owns the local store, does not have land of their own. As Harris (2006) wrote, "Taylor reverses the conventional social hierarchy, not just by placing the Logans, a minority family, at the center and marginalizing whites, but also by having the Logans paradoxically possess things that the whites around them covet, from water and land to cars and names" (p 106). Their ownership of land, places them in a position in the story to resist racism in a way that other Black families cannot (Taxel, 1991a; 1991b) What I personally like about this, however, is that it demonstrates that privilege is not a binary, but rather a spectrum 
that people fall within. The Logans are well aware of the power that their land gives them, and therefore will do anything to keep their land in-tact.

\section{Implications of this Comparison}

Both books present a specific view of prejudice, racism and injustice. To Kill a Mockingbird gives us a view through the eyes of a White child, whereas Roll of Thunder, Hear My Cry gives us a view through the eyes of a Black child. Both books have been highly praised, and both books have been criticized, censored and banned (American Library Association, n.d.). By looking at each girl's parental figures and familial advice, along with the history of land ownership, it seems to me that both books offer a complex yet differing portrait of the racial tensions of the time. However, when we do a close re-vision of these texts, To Kill a Mockingbird becomes a little more problematic. If we are to judge these two books and their approach to discussing racism, prejudice, privilege and justice, Harper Lee's book is the less "authentic" of the two, to me.

Cultural authenticity is tricky to define because it is difficult to verbalize exactly what it looks like. But, according to Sims Bishop (2003), it has two dimensions: "aspects of

the cultural, physical, or social environment the authors chose to emphasize" and "accuracy of authenticating details: grammatical and lexical accuracy of the characters' dialect, and taken-for granted information possessed by members of a cultural group" (p. 27-28). Doing a surface level reading of the two texts, I would argue that both books address issues of race equally well. However, when you define authenticity in terms of "whether a text ignored or downplayed cultural differences, rather than acknowledging and reflecting the distinctiveness of the culture being represented" (Sims Bishop, 2003, p. 27), To Kill a Mockingbird falls flat. 
Although many readers will undoubtedly claim that the Finch family is honest, good and innocent, and have grown throughout the course of the book, I believe it is important to note that stereotypes abound. Calpurnia is the epitome of the "Mammy" Black woman (Phelps, 2010). Also, Tom Robinson ironically fits the Uncle ‘Tom’ stereotype by being polite and subservient to Mayella Ewell, and ultimately acting as a martyr in order for the townspeople of Maycomb to see their prejudice ways. Helms (2010) wrote,

Tom is a stereotype. He is a good black man in a white racist society, where he is something other than an innocent victim. To Kill a Mockingbird would not be To Kill a Mockingbird, but a far more complex book telling a far more ambiguous and difficult story. Tom's options, as a representative good black man in a white racist society are, at best, limited. He is the sacrificial offering that defines the culture which offers it and that allows the good whites to show their goodness. (pp. 61-62) Upon closer examination, all African American characters in this novel are flat. None of them grow or change. Additionally, Saney (2003) argues that the Black characters are "robbed of their role as subjects of history, reduced to mere objects who are passive hapless victims; mere spectators and bystanders" (p. 102). Even Jem, someone who is highly sensitive to Tom Robinson's fate, lumps all Black people into one category, saying “There's four kinds of folks in the world. There's the ordinary kind like us and the neighbors, there's the kind like the Cunninghams out in the woods, the kind like the Ewells down at the dump, and the Negroes" (Lee, 1960, p. 161; emphasis added). As evidenced here, the Black characters become homogeneous, rather than acknowledged for their distinctiveness, as Sims Bishop (2003) argued. On the other hand, Roll of Thunder, Mildred Taylor 'consistently centers the black characters' agency and perspective. In doing so, it 
counters social conscience novels which often spotlight active white subjects who save the passive black victims of racial prejudice" (Barker, 2010, p. 130).

In addition, I think it is very important to also think about the perceptions of these portrayals within the African American population. Saney (2003) brings up the 2002 decision by the Black Educators Association (BEA) in Nova Scotia to remove To Kill a Mockingbird from the school curriculum because, according to the director, TKAM is "demeaning and offensive" to Black students. Initially the BEA won their request to take the book out of the curriculum, but then when the media caught wind of it, the Black community was chided and derided by the media and the White community, arguing that TKAM should be "lauded" as it is the "paragon of anti-racist literature," and therefore it is "untouchable" (Saney, 2003, p. 101). Other African American's have voiced similar sentiments, including Naomi Varnis, an African Studies student at Brown University, who asserted: “It's another practice of filtering stories about black people through white central characters" (Knight, 2015). These voices of black students need to be considered when thinking about the authenticity and merits of texts and the audiences for whom these texts are written.

Additionally, cultural authenticity entails discussions over "whether White writers, acculturated into a racialized society that grants them certain status and privilege denied to parallel culture groups are capable of transcending their acculturation to represent an 'insiders's' perspective on the lives of people from marginalized groups" (Sims Bishop, 2003, p. 28). Harper Lee is in one respect an outsider, due to the fact that she is White. However, Harper Lee grew up in the South and To Kill a Mockingbird is based off stories from her own childhood (Anderson, 2010; Murray, 2010, Newquist, 1964). So in this 
respect, she has garnered some credibility to write the stories of African American characters.

Interestingly, Sims Bishop (2003) noted that a culturally authentic text is "a story that captures the specifics and peculiarities of a people's experience [but] also captures something of the human experience, and thereby becomes 'universal'. This use of the term contrasts with a definition ...that eschews a difference and equates 'universal' with White middle-class American" (p. 30). On the one hand, it can be argued that To Kill a Mockingbird is a universal story in the positive way that does not essentialize, but rather captures an element of human experience we can all relate to. A story that is so loved, bettered only by the love of the Bible, must have some of this kind of universal appeal. Yet, at the same time, To Kill a Mockingbird also is universal in the not-so-culturally authentic way. Hovet and Hovet (2010), citing Robert Shulman, believe that Harper Lee utilizes "the middle-class, conversational voice that characterizes classical American realism" (p. 189). Furthermore, they believe that the middle-class narrative voice in To Kill a Mockingbird is appealing to so many readers because it, articulates what would become one of the dominant arguments of southern progressives, one uncritically echoed by many northern liberals. What some might see as virulent southern racism, the narrator tries to tell us, is not characteristic of the South as a whole but was created and sustained by a backward element in the rural South represented in the novel by the Ewell clan. (Hovet \& Hovet, 2010, p. 191)

In this way, Lee lets her White readers off the hook (Dillon, 2011) by implying, through her middle class voice, that racism is really just a redneck Ewell clan kind of racism. However, 
Taylor does the opposite by exploring racism from an insider perspective; therefore, "using authentic texts such as Roll of Thunder causes white readers (who do not usually see themselves as implicated by race or racism) to confront their racial subjectivity and privilege, perhaps for the first time in an in-depth way" (Saul \& Wallace, 2010, p. 50). Readers then are able to move outside of their comfort zones and uncritical cultural relativism that many multicultural texts provide, such as To Kill a Mockingbird.

\section{Re-Visioning These Texts in Our Classrooms}

If educators are to truly embrace Adrienne Rich's idea of "re-vision," then we must begin to see these texts with fresh eyes. I do hope that through a re-vision, it is clear that Roll of Thunder, Hear My Cry is worthy, if not more worthy, of the same accolades that have been bestowed on To Kill a Mockingbird. If you are a teacher looking to discuss with your students how to combat racism through a White perspective, then Harper Lee's book is definitely a great example of this. However, if a teacher has begun to question the authenticity of stories told through the White middle-class perspective, than Mildred Taylor's book offers teachers an opportunity to open up the discussion about racism and privilege beyond our society's very narrowly constructed view.

I do want to be careful and clear that I am not saying that educators should just stop teaching Harper Lee's book. Rather, instead, they should question why Mildred Taylor's book is not also an essential part of their curriculum, particularly since the book covers nearly equivalent topics, themes and characters. There are multiple (and many, many more) parallels to be found among these two texts that my paper could not delve into. Teachers also need to question why Roll of Thunder is labeled as children's literature, and not YA literature or even just plain literature. Nothing about this book screams children's 
literature, other than the fact that the main character is a child. Weirdly, To Kill a Mockingbird, is almost never defined as children's lit, despite the same exact fact. In fact, if this label of "children's literature" is an attempt to keep parallel culture literature out of the mainstream, it has been successful. But, we can do better. Middle, high school and college kids should have the opportunity to read Taylor's book and its moving story alongside To Kill a Mockingbird. This tandem approach has been successfully used by some scholars and educators already (Broz, 2011; Palumbo \& Sanacore, 2013; Ricker-Wilson, 1998).

Clearly, both books offer a unique perspective on racism, privilege, justice and discrimination. Yet, if we are to help our students see themselves represented in books, we need to offer a range of stories told through the eyes, lips, and fingers of writers who are actually from those diverse backgrounds. Whether one text is more authentic than the other is dependent upon whose point of view the reader is coming from. Whether our students are White, Black, Hispanic, or otherwise, each can gain valuable insights into the complexities of these topics by seeing a similar tale told from two completely different perspectives. Rather than discarding one story and replacing it with the other, reading both stories in tandem provides a unique opportunity to see a more well-rounded perspective of our world. To me, this is the most valuable lesson of comparing these two texts. 


\section{References}

American Library Association (n. d.). Top 100 banned/challenged books: 2000-2009. Retrieved from http://www.ala.org/bbooks/top-100-bannedchallenged-books2000-2009

Anderson, N. G. (2010). To Kill a Mockingbird: Successes and myths. In D. R. Noble (Ed.), Critical insights: To Kill a Mockingbird. (pp. 21-37). Pasadena, CA: Salem Press.

Apple, M. W. (2004a) Cultural politics and the text. In S. J. Ball (Ed.), The RoutledgeFalmer reader in Sociology of Education (pp. 179-195). New York, NY: RoutledgeFalmer.

Apple, M. W. (2004b). Ideology and curriculum. New York, NY: RoutledgeFalmer.

Applebee, A. N. (1990). Book-length works taught in high school English courses. ERIC Clearinghouse on Reading and Communication Skills.

Baecker, D. L. (2010). Telling it in black and white : The importance of the Africanist presence in To Kill a Mockingbird. In D. R. Noble (Ed.), Critical insights: To Kill a Mockingbird (pp. 205-222). Pasadena, CA: Salem Press.

Barker, J. L. (2010). Racial identification and audience in Roll of Thunder, Hear My Cry and the Watsons Go to Birmingham-1963. Children's Literature in Education, 41(2), 118-145.

Broz, W. J. (2011). Not reading: The 800-pound mockingbird in the classroom. English Journal, 100(5), 15-20

Children's Books Guide. (2012). 100 Best Children's Chapter Books of All-Time. Retrieved from http://childrensbooksguide.com/100-best-childrens-chapter-books-of-alltime Common Core State Standards Initiative. (2010). Common Core State Standards for English 
language arts \& literacy in history/social studies, science, and technical subjects.

Washington, DC: CCSSO \& National Governors Association. Retrieved from http://www.corestandards.org/assets/Appendix_B.pdf

Common Sense Media. (2014). 50 Books All Kids Should Read Before They're 12. Retrieved from https://www.commonsensemedia.org/lists/50-books-all-kids-should-readbefore-theyre-12

Cooperative Children's Book Center. (2010). 50 Multicultural Books Every Child Should Know. Retrieved from http://www.nea.org/grants/50-multicultural-books.html

Crowe, C. (1999). Young adult literature: Atticus, David, and Raymond: Role models for YA males. The English Journal, 88(6), 119-122.

Dillon, B. (2011). Still singing after all these years. Children's Literature, 39(1), 295-306. doi:10.1353/chl.2011.0001

Glazier, J., \& Seo, J. (2005). Multicultural literature and discussion as mirror and window? Journal of Adolescent \& Adult Literacy, 48(8), 686-700.

Harris, M. (2006). "A history not then taught in history books": (Re)writing reconstruction in historical fiction for children and young Adults. The Lion and the Unicorn, 30(1), 94-116.

Helms, N. (2010). “Were you ever a turtle?”: To Kill a Mockingbird-casting the self as the other. In D. R. Noble (Ed.), Critical insights: To kill a mockingbird. (pp. 50-67). Pasadena, CA: Salem Press.

Hovet, T., \& Hovet, G. (2010). "Fine fancy gentlemen" and "yappy folk": Contending voices in To Kill a Mockingbird. In D. R. Noble (Ed.), Critical insights: To kill a mockingbird. (pp. 187-205). Pasadena, CA: Salem Press. 
Jipson, J., \& Paley, N. (1991). The selective tradition in teachers' choice of children's literature: Does it exist in the elementary classroom? English Education, 23(3), 148159.

Juzwik, M. M. (2013). The ethics of teaching disturbing pasts: Reader response, historical contextualization, and rhetorical (con)textualization of Holocaust texts in English. English Education, 45(3), 284-308.

Knight, H. (2015, March 2). To Kill a Mockingbird: The first YA novel? BBC Campus. Retrieved from http://www.bbc.com/culture/story/20150302-the-first-ya-novel

L'Engle, M. (2001). Walking on water: Reflections on faith and art. Colorado Springs, CO: Waterbrook Press.

Lacayo, R., \& Grossman, L. (2010, January 6). All-TIME 100 Novels. Retrieved from http://entertainment.time.com/2005/10/16/all-time-100-novels/

Lee, H. (1960). To kill a mockingbird. New York: Warner Books, Inc.

Luke, A. (1991). Literacies as social practices. English education, 23(3), 131-147.

Martorana, C. M. (2013). Rhetorical approaches to texts: Expanding our definition of rhetoric. English Education, 45(3), 213-217.

McDowell, K. (2002). Roll of Thunder, Hear My Cry: A culturally specific, subversive concept of child agency. Children's Literature in Education, 33(3).

McNair, J. C. (2010). Classic African American children's literature. The Reading Teacher, 64(2), 96-105.

Modern Library. (1998). 100 Best Novels. Retrieved from http://www.modernlibrary.com/top-100/100-best-novels/ 
Modern Library. (1998). Radcliffe's Rival 100 Best Novels List. Retrieved from http://www.modernlibrary.com/top-100/radcliffes-rival-100-best-novels-list/

Murray, J. (2010). More than one way to (Mis)read a mockingbird. The Southern Literary Journal, 43(1), 75-91.

National Education Association. (2000). Kids' Top 100 Books. Retrieved from http://www.nea.org/grants/kids-top-100-books.html

Newquist, R. (1964). Interview with Harper Lee. Counterpoint. Chicago: Rand McNally. Nodelman, P. (2008). The hidden adult: Defining children's literature. Baltimore, MD: Johns Hopkins University Press.

National Public Radio. (2012, August 7). Your Favorites: 100 Best-Ever Teen Novels. Retrieved from http://www.npr.org/2012/08/07/157795366/your-favorites-100best-ever-teen-novels

Palumbo, A., \& Sanacore, J. (2013). Serious ideas and middle school students. The Educational Forum, 77(2), 192-198. doi:10.1080/00131725.2012.760698

Phelps, T. (2010). The margins of Maycomb: A rereading of To Kill a Mockingbird. In D. R. Noble (Ed.), Critical insights: To kill a mockingbird (pp. 165-187). Pasadena, CA: Salem Press.

Rich, A. (1972). When we dead awaken: Writing as re-vision. College English, 34(1), 18-30.

Ricker-Wilson, C. (1998). When the mockingbird becomes an albatross: Reading and resistance in the language arts classroom. The English Journal, 87(3).

Saul, W., \& Wallace, K. (2002). Centering the margins: White preservice teachers' responses to Roll of Thunder. Teaching Education, 13(1), 41-53.

doi:10.1080/1047210120128573 
Silvey, A. (2004). 100 best books for children. Boston: Houghton Mifflin.

Sims, R. (1982). Shadow and substance: Afro-American experiences in contemporary children's fiction. Urbana, IL: National Council of Teachers of English.

Sims Bishop, R. (2003). Reframing the debate about cultural authenticity. In D. L. Fox \& K. G. Short (Eds.), Stories Matter: The Complexity of Cultural Authenticity in Children's Literature (pp. 25-37). Urbana, IL: NCTE.

Sims Bishop, R. (2012). Reflections on the development of African American Children's Literature. Journal of Children's Literature, 38(2), 5-13. doi:10.1037/h0081733

Taxel, J. (1991a). Reclaiming the voice of resistance: The fiction of Mildred Taylor. In L. Christian-Smith and M. W. Apple (Eds.), The politics of the textbook. London: Routledge and Kegan Paul.

Taxel, J. (1991b). Roll of thunder, hear my cry: Reflections on the aesthetics and politics of children's literature. In W. Schubert and G. Willis (Eds.). Reflections from the heart of educational inquiry: Understanding curriculum and teaching through the arts. Albany N. Y.: SUNY Press.

Taylor, M.D. (1976) Roll of thunder, hear my cry. New York: Puffin Books.

Taylor, M. D. (1985). Roll of thunder, hear my cry Newbery Medal acceptance speech. The Horn Book Magazine, 1-5.

Watkins, N., \& Ostenson, J. (2015). Navigating the text selection gauntlet : Exploring factors that influence English teachers' choices. English Education, 47(3), 245-275.

Williams, R. (1977). Marxism and literature. London: Oxford University Press.

Wollman-Bonilla, J. E. (1998). Outrageous viewpoints: Teachers' criteria for rejecting works of children's literature. Language Arts, 75(4), 287-295. 
YALSA. (n.d.). The Ultimate YA Bookshelf. Retrieved from http://www.ala.org/yalsa/ professionaltools/yabookshelf\#ultimate 